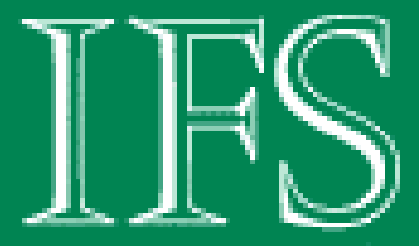

\title{
TwO CHEERS FOR THE PENSION CREDIT?
}

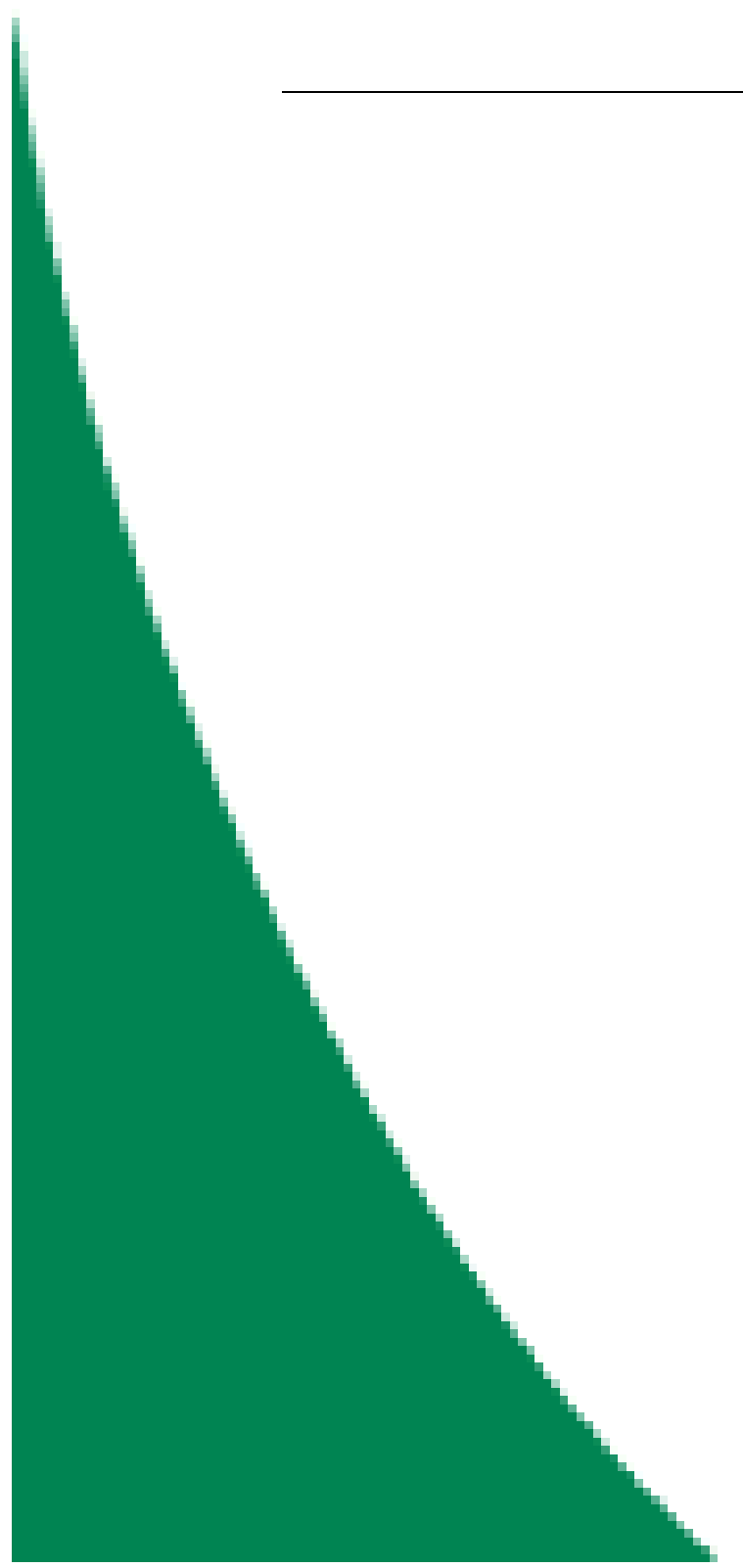

Mike Brewer

Carl Emmerson 


\title{
Two Cheers for the Pension Credit?
}

\author{
Mike Brewer and Carl Emmerson* \\ Institute for Fiscal Studies
}

\section{Introduction}

On 6 October 2003, the pension credit replaced the minimum income guarantee as the principal means-tested benefit for families containing an individual aged 60 or over. This Briefing Note examines the impact of this reform. A finding is that with regards to the government's objectives of giving more resources to low- to middle-income pensioners, rewarding pensioners for having saved in the past and encouraging people of working age to save for the future, the pension credit is likely to achieve the first two but not the third.

This Briefing Note is set out as follows. Section 2 describes how the pension credit operates and why the problems that occurred with the Inland Revenue's administration of the new tax credits for families with children in April 2003 should not occur with the pension credit. The distributional impact of the reform is shown in Section 3. Section 4 discusses the inevitable problem of incomplete take-up of the new payment. Section 5 discusses the likely impact of the pension credit on saving and Section 6 discusses some of the longer-term issues that it raises. Section 7 concludes.

\section{What is the pension credit?}

The pension credit is the principal means-tested benefit for families containing an individual aged 60 or over. It replaced the minimum income guarantee (MIG), which itself replaced income support for those aged 60 or over just four-and-a-half years ago in April 1999. The pension credit is more generous

\footnotetext{
*Address for correspondence: Institute for Fiscal Studies, 7 Ridgmount Street, London, WC1E 7AE or email Mike_Brewer@ifs.org.uk or Carl_Emmerson@ifs.org.uk. Financial support from the ESRC-funded Centre for the Microeconomic Analysis of Public Policy at IFS (grant number M535255111) is gratefully acknowledged. The authors thank Robert Chote and Matthew Wakefield for useful comments. Any errors and all opinions expressed are those of the authors.
} 
than the MIG to lower-income families including an individual aged 65 or over. For other families, it is of equal generosity to the MIG.

The operation of the MIG prior to October 2003 is shown for a single pensioner in Figure 1. Those who had an income below £102.10 a week and claimed the benefit had their income topped up to this level. This is shown by the horizontal part of the final income line. It worked in a similar way for couples, except that they could receive a higher amount. Ignoring for now the problem of incomplete take-up, which is discussed in Section 4, it is clear that government expenditure on the MIG was extremely well targeted on the poorest pensioners. This was achieved by a $100 \%$ effective marginal withdrawal rate - i.e. every additional $£ 1$ of income that an individual in receipt of the MIG received led to a $£ 1$ reduction in their MIG entitlement. This $100 \%$ effective marginal withdrawal rate led to two interrelated problems:

- People would have no incentive to save for retirement if they knew that their savings would yield an income of less than that provided by the MIG (£102.10 a week in 2003-04). Entitlement to the MIG meant that giving up consumption during their working life would not lead to a higher income to finance higher consumption during their retirement. Extra income from savings would simply move an individual along the horizontal part of the budget constraint in Figure 1. Estimates suggest that, assuming that the basic state pension was indexed in line with prices and the MIG was indexed in line with average earnings, an annuity costing around $£ 37,000$ would be required for a man aged 65 with no other private income to be ineligible for the MIG. ${ }^{1}$

- Those in retirement who had saved a small amount received the same amount of income as those who had not saved at all. Again as shown in Figure 1 , an individual with $£ 10$ or $£ 20$ of weekly pension income in addition to the basic state pension would receive the same amount of total income in retirement as an individual who had not made any additional pension provision. This was perceived as unfair, as people who saved in the past would see no reward for it.

\footnotetext{
${ }^{1}$ The cost of purchasing an annuity equal to the MIG is around $£ 97,000$, while the cost of purchasing an annuity equal to the basic state pension is around $£ 60,000$. Therefore the difference is around $£ 37,000$. Were the MIG only to be indexed in line with prices, this difference would fall to around $£ 18,000$. Source: memorandum submitted by Deborah R. Cooper to the Department for Work and Pensions Select Committee; see appendix 63, Ev404-Ev405, of House of Commons Work and Pensions Committee, The Future of UK Pensions, Third Report of Session 2002-03, Volume II, London, 2003 (www.publications.parliament.uk/pa/cm200203/cmselect/cmworpen/92/92ap64.htm).
} 
Figure 1. Illustrative budget constraint under the minimum income guarantee for a single pensioner in receipt of a full basic state pension, April 2003

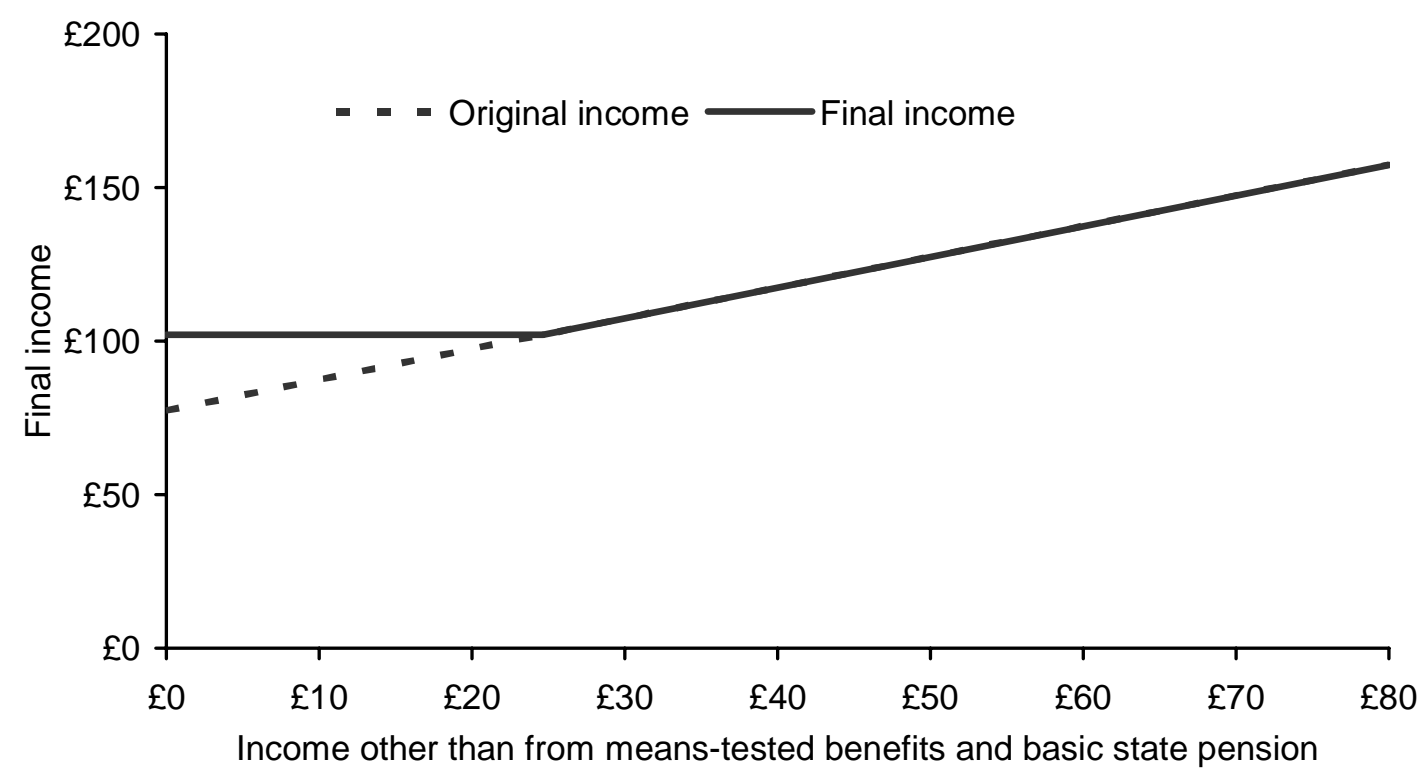

Note: Income disregards, taxation and other means-tested benefits ignored.

Figure 2. Effect of the pension credit on the final income of a single pensioner aged 65 or over in receipt of a full basic state pension, October 2003

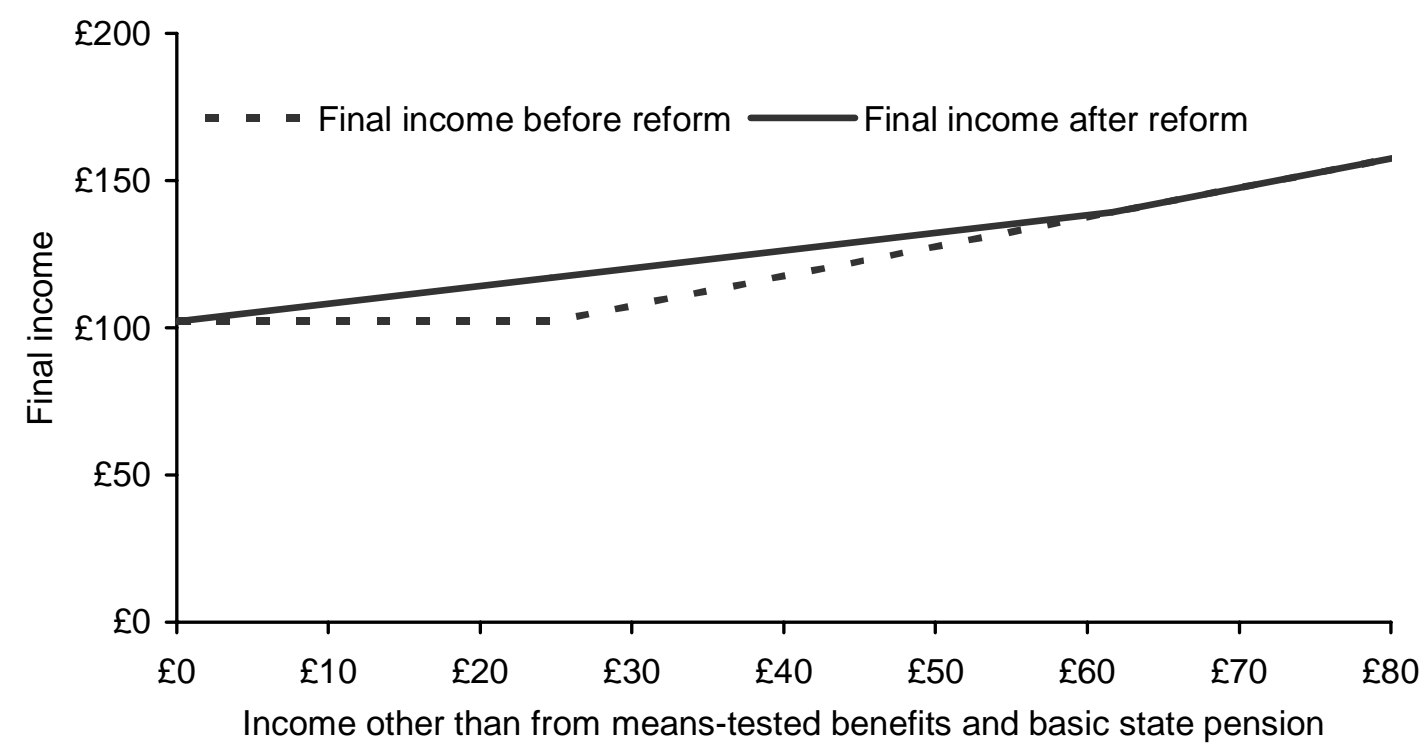

Note: Income disregards, taxation and other means-tested benefits ignored. 
As a result of these two problems and a desire to continue to increase the incomes of poorer pensioners, the government proposed the new pension credit in November 2000. ${ }^{2}$ Its final design is shown in Figure 2 for a single individual aged 65 or over. The key difference between the pension credit and the minimum income guarantee is that under the pension credit individuals aged 65 or over who are in receipt of the full basic state pension face a $40 \%$ withdrawal rate instead of the previous $100 \%$ one. ${ }^{3}$ This means that they keep 60 pence out of every $£ 1$ of additional income. This is shown by the upward slope of the budget constraint in Figure 2 between $£ 0$ and $£ 62$ per week of income other than from means-tested benefits and basic state pension. Individuals aged 60 to 64 and those who are not in receipt of the full basic state pension can still face the same $100 \%$ effective marginal withdrawal rate as under the MIG system.

\section{Will the introduction of the pension credit have the same administrative problems as the introduction of the new tax credits?}

The introduction of the child tax credit and working tax credit in April 2003 was dogged by the considerable administrative difficulties experienced by the Inland Revenue. These led to substantial delays in time taken to process claims. Many thousands of families went without payments for several weeks. ${ }^{4}$ There are good reasons to think that such difficulties will not occur with the introduction of the pension credit.

The introduction of the new tax credits affected over 4 million families, and the new tax credits system began for all these families on the same day. In order to process the new tax credits, the Inland Revenue needed to build a new IT system.

The pension credit also affected a very large number of families, but the Department for Work and Pensions (DWP) has not had to build a new computer system to administer it, and it is not attempting a 'big bang'

\footnotetext{
${ }^{2}$ See Department of Social Security, The Pension Credit: A Consultation Paper, London, TSO, 2000 (www.dwp.gov.uk/consultations/consult/2000/pencred/pencred.pdf). For a response to this initial consultation, see T. Clark, Recent Pensions Policy and the Pension Credit, Briefing Note no. 17, Institute for Fiscal Studies, London, 2001 (www.ifs.org.uk/pensions/bn17.pdf).

${ }^{3}$ The impact of other benefits is ignored here but considered in Tables 1 and 2.

${ }^{4}$ The Treasury Select Committee reported that 'at 2 July some 220,000 applications (just under $5 \%$ of the total) had not been resolved. Over 100,000 of these unresolved applications had been received more than a month earlier. As a result of delays, the Revenue has made nearly 200,000 emergency payments through its local offices. Over 400,000 applicants (or 7\% of the total) received their first payment on a later date than the one they had been notified of ... A "flagship project" in the important reform programme that will integrate tax and benefits got off to an unfortunate start' (House of Commons Treasury Committee, Inland Revenue Matters, Tenth Report of Session 2002-03, HC 834, TSO, London, 2003 (www.parliament.the-stationery-office.co.uk/pa/cm200203/cmselect/cmtreasy/834/834.pdf)).
} 
introduction of the pension credit. Instead, there is to be a phased introduction of the pension credit:

- People who were claiming the MIG in September 2003 will automatically be transferred to the pension credit in October 2003. This will ensure that existing recipients do not go without benefits.

- A total of 1.3 million families containing an individual aged 65 or over, or $36 \%$ of those eligible for the pension credit, were not previously entitled to the MIG. Until October 2004, the DWP is allowing these families to backdate claims for the pension credit to October 2003. It hopes that this will reduce the pressure to process a large number of claims in a short space of time. Although these families may have to wait several months before receiving their pension credit, they were not previously entitled to receive the MIG, and so the delay will not make them any worse off.

\section{Who will gain from the pension credit?}

The full-year cost of the pension credit reform is estimated by the government at $£ 2$ billion a year, although it will only cost $£ 1$ billion in 2003-04 because it is being introduced in October 2003. ${ }^{5}$ Figure 2 showed that those gaining from the pension credit are those individuals aged 65 or over who are on low to moderate incomes - namely, those on incomes of under $£ 140$ a week. Those on the lowest incomes who were receiving the minimum income guarantee will not gain as much as they would have if the additional resources had been spent on an increase in the MIG.

In total, we estimate that there are 3.6 million families containing an individual aged 65 or over in the UK that are eligible for the pension credit, out of a total of 6.6 million in this age group. ${ }^{6}$ This compares with the 2.3 million families containing an individual aged 65 or over estimated to have been eligible to the MIG. The pension credit reform also increases the number of individuals who are eligible for housing benefit and council tax benefit. In total, we estimate that 4.2 million families containing an individual aged 65 or over are eligible for means-tested benefits (i.e. pension credit, housing benefit or council tax

\footnotetext{
${ }^{5}$ Costings taken from table A.2 of HM Treasury, Financial Statement and Budget Report, HC 592, TSO, London, 2002 (www.hmtreasury.gov.uk/budget/bud_bud02/budget_report/bud_bud02_repchapa.cfm). Estimates from T. Clark, Rewarding Saving and Alleviating Poverty? The Final Pension Credit Proposals, Briefing Note no. 22, Institute for Fiscal Studies, London, 2002 (www.ifs.org.uk/pensions/bn22.pdf) suggest that around three-quarters of this expenditure is on the pension credit, with the remainder split approximately equally between additional expenditure on housing benefit and additional expenditure on council tax benefit.

${ }^{6}$ Note that these figures do not include those living in nursing or residential care homes. Estimates in this paragraph come from the IFS tax and benefit model, TAXBEN, using data from the 1998-99 Family Resources Survey.
} 
benefit) after the pension credit reform. This compares with 3.7 million families before the reform. ${ }^{7}$ These figures are looked at in more detail in Table 2.

Figure 3. Gains from the pension credit across the whole income distribution

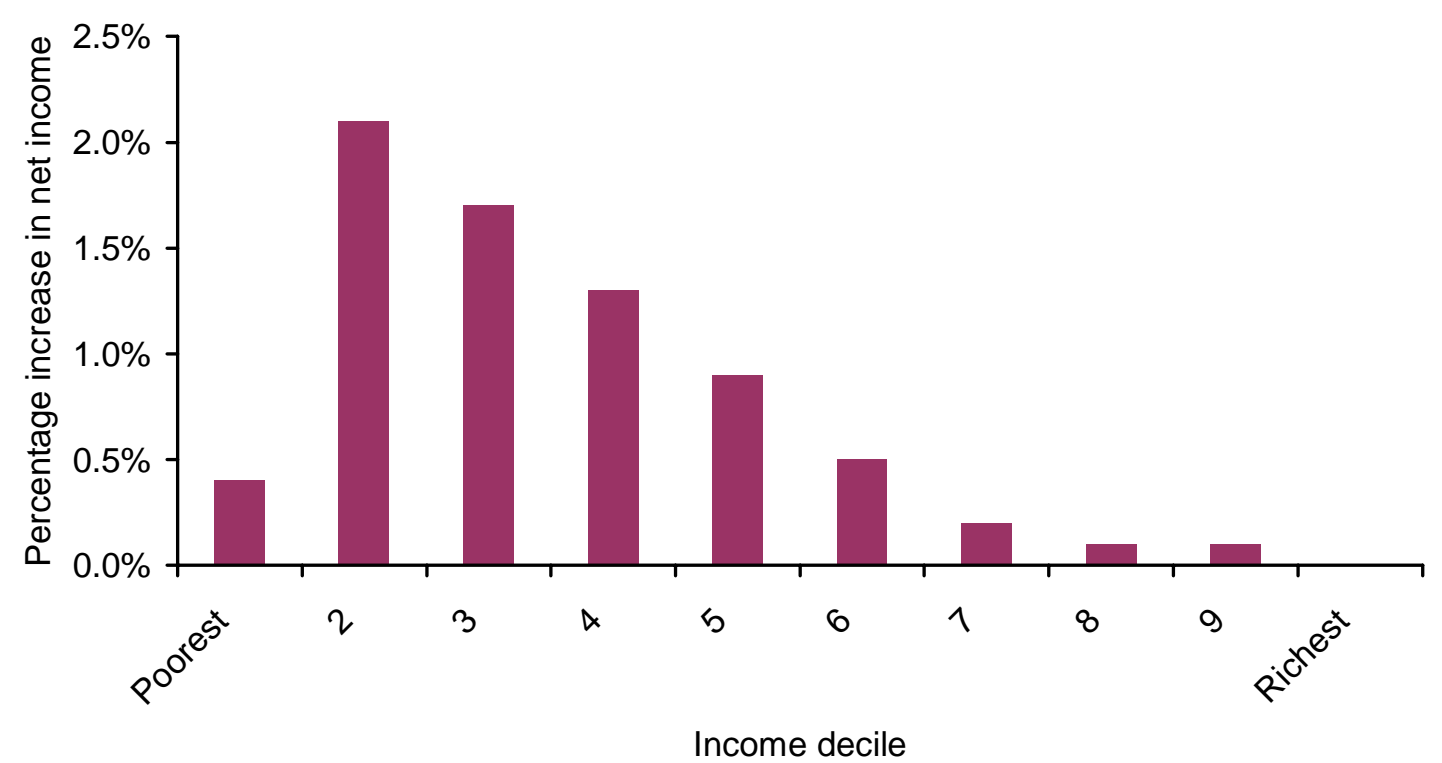

Note: Income deciles are derived by dividing the total population into 10 equally sized groups according to household income adjusted for family size. Decile 1 contains the poorest tenth of the population, decile 2 the next poorest tenth and so on, up to the richest tenth in decile 10.

Source: T. Clark, Rewarding Saving and Alleviating Poverty? The Final Pension Credit Proposals, Briefing Note no. 22, Institute for Fiscal Studies, London, 2002 (www.ifs.org.uk/pensions/bn22.pdf).

How the gains from the pension credit reform are spread across the entire income distribution is shown in Figure 3. The graph assumes that all families who are entitled to the pension credit and other means-tested benefits actually claim them. On average, the second decile receives the largest increase in net income, of $2.1 \%$, with the gains declining as we move further up the income distribution. The poorest income decile also gains less. This is due to the fact that there are relatively fewer individuals aged 65 or over in this decile of the overall population income distribution. ${ }^{8}$

\footnotetext{
${ }^{7}$ The number of individuals in families containing an individual aged 65 or over entitled to the pension credit is estimated to be 4.6 million. This compares with 2.8 million entitled to the MIG. A total of 5.5 million individuals in families containing an individual aged 65 or over are estimated to be eligible for means-tested benefits after the pension credit reform, compared with a total of 4.8 million before the reform. There are a total of 9.4 million individuals in families containing an individual aged 65 or over.

${ }^{8}$ For a discussion of the position of pensioners in the overall income distribution over time, see A. Goodman, P. Johnson and S. Webb, Inequality in the UK, Oxford University Press, Oxford, 1997, or A. Goodman and A. Shephard, Inequality and Living Standards in Great
} 
Figure 4. Gains from the pension credit across the income distribution of those aged 65 or over

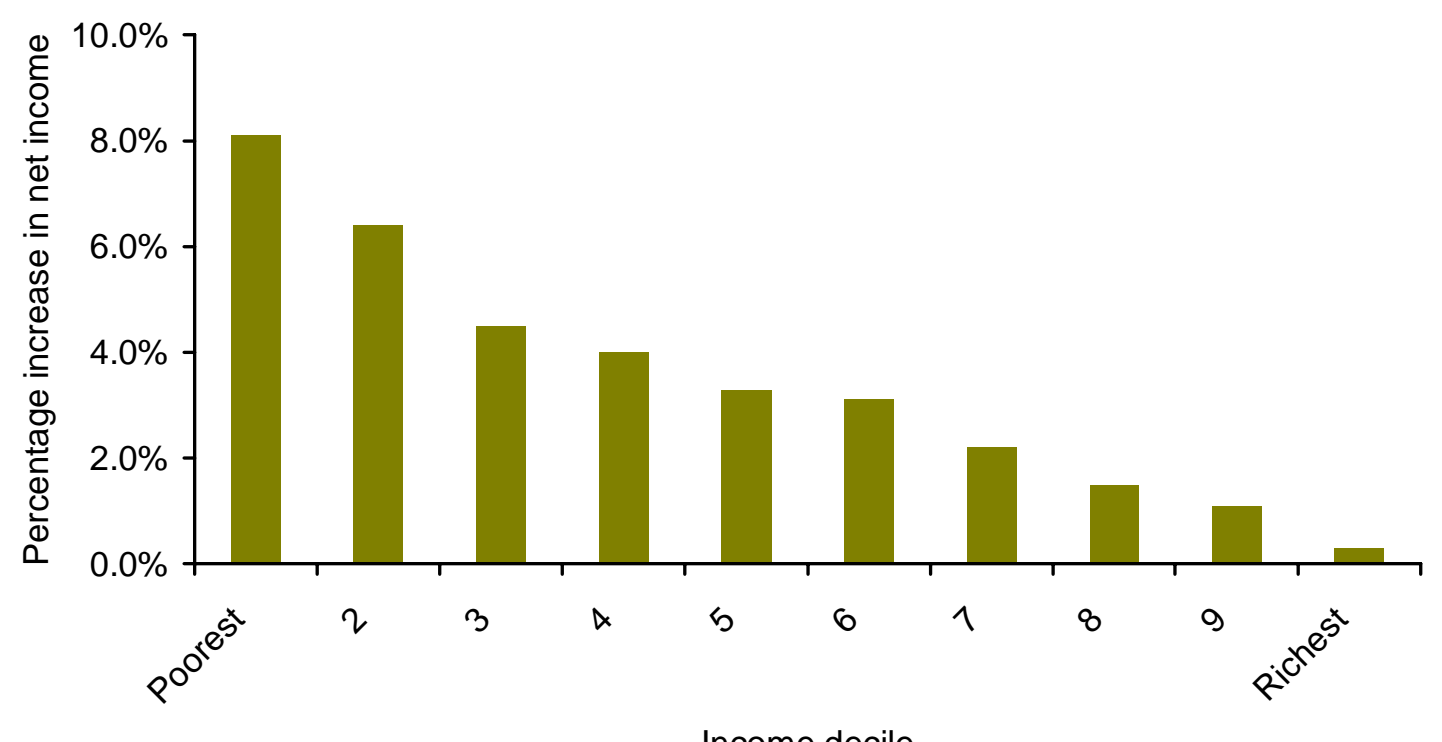

Note: As Figure 3.

Source: As Figure 3.

The gains across the income distribution of individuals aged 65 or over, rather than across the whole population, are shown in Figure 4. If all entitled families claim the pension credit and other means-tested benefits, the poorest tenth of these families gain by an average of $8.1 \%$, while the richest tenth gain an average of just $0.3 \%$. In cash terms, those in the bottom decile still gain on average the most.

\section{What will take-up of the pension credit be?}

The key attraction of a means-tested benefit for pensioners is that it allows for large increases in the incomes of the poorest pensioners at less cost than if benefits are paid universally to all pensioners. One of the main downsides is that many pensioners do not claim the means-tested benefits to which they are entitled.

Official statistics suggest that between $24 \%$ and $32 \%$ of families entitled to the MIG did not claim in 2000-01 (between 450,000 and 670,000 families). In the same year, between $32 \%$ and $38 \%$ of pensioners entitled to council tax benefit did not claim it (between 1,100,000 and 1,430,000 families) and one in ten did not claim their housing benefit entitlement (between 110,000 and 270,000 families). These rates of non-take-up are substantially higher than those

Britain: Some Facts, Briefing Note no. 19, Institute for Fiscal Studies, London, 2002 (www.ifs.org.uk/inequality/bn19.pdf). 
amongst the non-pensioner population. ${ }^{9}$ Although those pensioners who do not claim tend to be entitled to small amounts, pensioner poverty would fall if everyone received the benefits to which they are entitled. ${ }^{10}$

People may not claim the benefit to which they are entitled for a number of reasons. These can be classified into three main categories:

- lack of information concerning eligibility;

- hassle and difficulties in claiming (for example, the time necessary to fill in the application and/or difficulties in reading or understanding the claim form);

- stigma associated with claiming means-tested support.

The Department for Work and Pensions commissioned research on why pensioners do not claim the benefits to which they are entitled. It found that there was a relatively large group - $40 \%$ of those who were not claiming benefits to which they were entitled - who tended not to claim because they did not know that they were eligible. But there was another group - just under a quarter of those who were entitled but did not claim - who were 'extremely averse to claiming Income Support in its present guise, because of underlying attitudes towards income-related benefits and the anticipated claim process'. ${ }^{11}$

These relatively low rates of take-up could seriously limit the government's ability to help lower-income pensioners by using the pension credit. The government hopes that these families can be persuaded to claim, for the following reasons:

- The claim form for the pension credit is simpler and less intrusive than the claim forms for income support and the MIG. Once assessed, awards usually last for five years; under the MIG, pensioners potentially faced fines

\footnotetext{
${ }^{9}$ The respective rates of non-take-up measured by expenditure are all lower than the rates by caseload. For the latest figures, see Department for Work and Pensions, Income Related Benefits: Estimates of Take-Up in 2000/2001, London, 2003 (www.dwp.gov.uk/asd/income_analysis/tu0001.pdf). This section updates A. Goodman, M. Myck and A. Shephard, Sharing in the Nation's Prosperity? Pensioner Poverty in Britain, Commentary no. 93, Institute for Fiscal Studies, London, 2003 (www.ifs.org.uk/inequality/comm93.pdf).

${ }^{10}$ A. Goodman, M. Myck and A. Shephard, Sharing in the Nation's Prosperity? Pensioner Poverty in Britain, Commentary no. 93, Institute for Fiscal Studies, London, 2003 (www.ifs.org.uk/inequality/comm93.pdf).

${ }^{11}$ P. Costigan, H. Finch, B. Jackson, R. Legard and J. Ritchie, Overcoming Barriers: Older People and Income Support, DSS Research Report no. 100, CDS, Leeds, 1999. The interviews on which the research is based were carried out in 1998.
} 
if they did not immediately report any change in income or other circumstances to the DWP.

- The government has created a new Pension Service to help pensioners claim the benefits to which they are entitled. Although they will still need to provide information on their sources of income and financial assets, individuals can claim the pension credit over the telephone.

- The government has been advertising the pension credit, and will write to all individuals aged 60 or over to help them decide whether to apply for the pension credit. The advertising materials seem to be designed to try to reduce feelings of stigma about receiving means-tested benefits by portraying them as an entitlement (for example, the Pension Service is using the slogan 'Pick It Up. It's Yours').

The fact that many more pensioner families are now entitled to the pension credit may itself increase the likelihood that individuals claim it, since there may be less stigma associated with a more widespread payment.

The potential increased take-up and reduced administrative burden of the fiveyear period between claims are not without cost. The more infrequent the period between (re)assessments, the less well targeted at current needs the pension credit will be. Those whose incomes fall can choose to re-apply for a higher award. Others might experience an increase in their income and continue to receive more pension credit than they would be entitled to were they to be reassessed. As a result, the pension credit would become less well targeted at lower-income pensioners.

The DWP has a Public Service Agreement to pay the pension credit to at least 3 million pensioner households by 2006, compared with the 1.8 million families receiving the MIG in May 2003. This represents a take-up target of $73 \%{ }^{12}$ To meet this target, the government needs to persuade around 1.2 million additional families to claim. But if the government hits its target precisely, then 950,000 lower-income households that are eligible for the pension credit will still not be taking it up.

\section{Will the pension credit increase retirement saving?}

The government has a stated objective to increase the percentage of pension income from private sources from 40\% in 1998 to $60 \%$ by the middle of this century. ${ }^{13}$ Therefore a key policy issue is whether the pension credit reform

\footnotetext{
${ }^{12}$ Source: House of Commons Hansard, Oral Answers, Mr Andrew Smith, Secretary of State for Work and Pensions, 7 July2003: column 735.

${ }^{13}$ Paragraph 41, page 8 of Department of Social Security, A New Contract for Welfare: $\begin{array}{llll}\text { Partnership in Pensions, Cm. 4179, London, } 1998 & \end{array}$ (www.dwp.gov.uk/publications/dss/1998/pengp/main/main_index.asp).
} 
will lead to an increase or a reduction in private saving for retirement. The government has stressed the following:

The Pension Credit represents a fundamental reform to the welfare system - for the first time, saving will be rewarded instead of being penalised. The Pension Credit will ensure that pensioners who have saved modest amounts - whether it is through an occupational scheme, a stakeholder or personal pension, the State Second Pension or other savings - will gain from having done so. ${ }^{14}$

It is true that an individual who will receive the pension credit in retirement will now receive a higher retirement income if they increase their retirement saving while in work. This is shown by the fact that the 'Final income after reform' line in Figure 2 is upward sloping. The operation of the MIG meant that recipients with small amounts of private income received the same total income as recipients with no private income. (This is shown by the horizontal part of the 'Final income before reform' line in Figure 2.) Individuals aged 60 to 64 and those who do not qualify for the full basic state pension can still face a $100 \%$ effective marginal withdrawal rate under the pension credit and therefore will find that they are still not rewarded for their saving.

Rewarding saving is not the same as increasing saving. Economic theory can tell us whether some individuals are likely to save more, less or the same as a result of the pension credit reform. For others, the impact is ambiguous. The reform will have two effects, known as a substitution effect and an income effect:

- Substitution effect. A fall (rise) in the effective marginal withdrawal rate faced by an individual on their retirement income will increase (reduce) their marginal incentive to save for retirement while in work. This is because the reward from additional saving is increased (reduced).

- Income effect. The larger the income from the state that an individual expects to receive in retirement, the smaller their need to save privately for retirement income. For example, if the state promises to be more generous, then achieving a given level of retirement income will require less saving during an individual's working life.

The overall impact of these two effects varies across four types of individuals:

1. Those with a small amount of private savings who expect to receive the pension credit, along with a full basic state pension, and who would have expected to receive the MIG, will see their expected effective marginal

\footnotetext{
${ }^{14}$ Quote taken from page 4 of Department for Work and Pensions, The Pension Credit: The $\begin{array}{lll}\text { Government's } \quad \text { Proposals, } & \text { London, }\end{array}$ (www.dwp.gov.uk/publications/dwp/2001/pencred/pencred.pdf).
} 
withdrawal rate in retirement fall. (This is marked as range B on Figure 5.) This substitution effect will increase their retirement saving. However, they will also expect to be better off in retirement as a result of the reform. This income effect will reduce their retirement saving. The overall impact of these two offsetting effects is not known and is an interesting empirical question for future research.

2. Those who expect to be eligible for means-tested benefits as a result of the reform will see their effective marginal withdrawal rate rise. (This is marked as range $C$ on Figure 5.) This substitution effect will reduce their retirement saving. In addition, they will expect to be better off in retirement as a result of the reform. This income effect will also reduce their retirement saving. Hence, according to economic theory at least, individuals in this category will reduce their retirement saving. This group could be quite large. For example, if the basic state pension is indexed in line with prices and the pension credit in line with average earnings, then an annuity costing around $£ 78,000$ would be required for a man aged 65 with no other private income to be ineligible for the pension credit. ${ }^{15}$ The implications of this differential indexation are discussed in more detail in Section 6.

3. Those with no private savings who expect to receive the pension credit along with a full basic state pension will see their effective marginal withdrawal rate fall. (This is marked as point A on Figure 5.) This substitution effect will increase their retirement saving. In the absence of any private saving, the pension credit will not make them any better off. Thus there is no income effect. Hence, according to economic theory at least, individuals in this category will either choose to continue saving nothing for their retirement or they might choose to increase their retirement saving.

4. Those who do not expect to be eligible for the pension credit (marked as range D in Figure 5) will find that if they reduce their retirement saving, then their retirement income will drop by less than it would have done before the pension credit reform. This substitution effect might lead to them choosing to save less. There is no income effect. Hence, according to economic theory at least, individuals in this category will either leave their saving unchanged or choose to save less as a result of the reform.

\footnotetext{
${ }^{15}$ Using the values set out in footnote 1 , an income equivalent to that provided by an annuity costing around $£ 138,000$ would be needed to exhaust entitlement to the pension credit. As the basic state pension is equivalent in value to an annuity costing $£ 60,000$, the difference is around $£ 78,000$. Were the pension credit only to be indexed in line with prices, this difference would drop to around £51,000.
} 
Figure 5. The key groups for whom economic theory suggests that the pension credit will alter retirement saving incentives

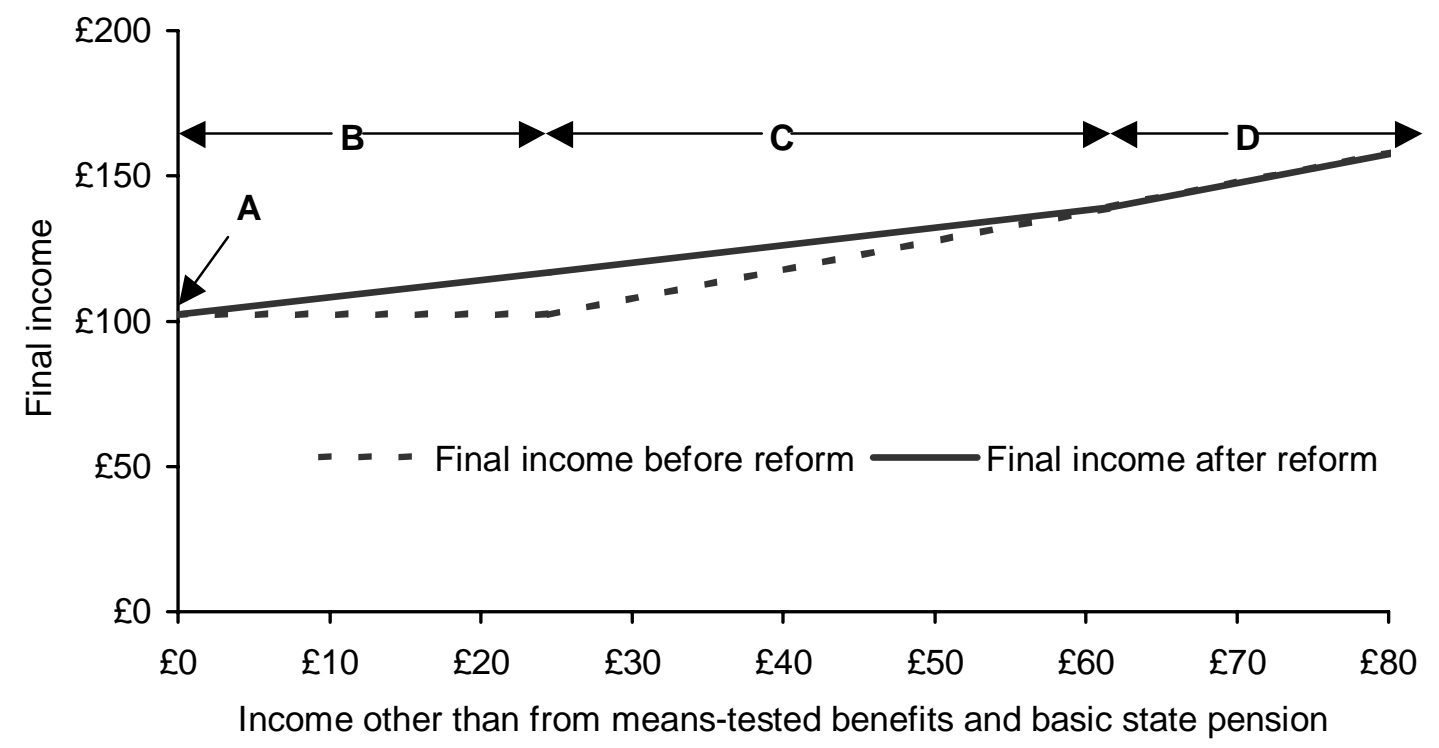

Note: Income disregards, taxation and other means-tested benefits ignored.

The net impact of the pension credit on overall private saving rates is uncertain. It will depend on the responsiveness of the saving of each of these four groups and the numbers in each group. It is difficult to know the group sizes as they will depend on the expected retirement incomes of the current working-age population. In addition, it is possible that many individuals do not fully understand how the system operates in terms of expected state support for a given level of private retirement saving. If this is the case, predicting the responsiveness of individuals to changing saving incentives is even more complicated. However, it should be noted that the group for which economic theory expects a reduction in retirement saving (marked by range $\mathrm{C}$ in Figure 5) consists of higher-income individuals than those where economic theory is ambiguous or where it suggests there might be an increase in retirement saving (marked, respectively, by range B and point A in Figure 5). This suggests that the aggregate impact of the policy on overall private retirement saving might be negative. The overall impact on overall aggregate saving (i.e. private saving plus public saving) is very likely to be negative, given the £2 billion annual cost of the pension credit reform to the exchequer. This suggests that the main effect of the pension credit is to redistribute towards low- to middle-income pensioners, rather than to increase retirement saving.

As the substitution effect is key to the extent to which the pension credit leads to individuals saving more or less for their retirement, we now turn to examine the impact of the reform on marginal incentives more closely. The pension credit is withdrawn at a rate of $40 \%$. But interactions with other benefits can create much higher effective marginal withdrawal rates. People simultaneously 
on the tapers of housing benefit, council tax benefit and the pension credit will face a combined effective marginal withdrawal rate of $91 \%{ }^{16}$

While some individuals will continue to face extremely high effective marginal withdrawal rates, the pension credit reform does in fact reduce the number of individuals in this position. Table 1 shows that the percentage of individuals aged 65 or over who face an effective marginal withdrawal rate of $100 \%$ or higher is reduced from $32.1 \%$ to just $5.6 \%$. In addition, the mean effective marginal tax rate is reduced by the reform, and a larger number of adults will see a reduction in the withdrawal rate that they face than the number that will see an increase. Working in the opposite direction, however, there is a decline in the number of individuals facing a $0 \%$ effective marginal withdrawal rate. This pattern - fewer individuals facing very high marginal withdrawal rates, fewer individuals facing very low or zero marginal withdrawal rates, but more individuals facing marginal withdrawal rates between $50 \%$ and $70 \%$ - is broadly the same as the impact of the Labour government's reforms on working-age families with children. ${ }^{17}$

Table 1. Percentage of adults aged 65 or over facing various effective marginal withdrawal rates, before and after the pension credit reform

\begin{tabular}{l|ccc}
\hline Effective marginal withdrawal rate & Pre-reform & Post-reform & $\begin{array}{c}\text { Change } \\
\text { (\% points) }\end{array}$ \\
\hline $0 \%$ & $18.2 \%$ & $13.5 \%$ & -4.7 \\
$>0 \%,<50 \%$ & $42.2 \%$ & $56.7 \%$ & +14.5 \\
$50 \%-69.9 \%$ & $0.6 \%$ & $14.9 \%$ & +14.3 \\
$70 \%-79.9 \%$ & $0.5 \%$ & $0.4 \%$ & -0.1 \\
$80 \%-89.9 \%$ & $5.5 \%$ & $1.3 \%$ & -4.2 \\
$90 \%-99.9 \%$ & $1.0 \%$ & $7.7 \%$ & +6.7 \\
$100 \%+$ & $32.1 \%$ & $5.6 \%$ & -26.5 \\
\hline
\end{tabular}

Notes: The percentages represent fractions of the total population of adults aged 65 or over in private households in Great Britain. Their total number is 8.54 million. Withdrawal rates are estimated by considering the effect of an increase in private pension income.

Source: T. Clark, Rewarding Saving and Alleviating Poverty? The Final Pension Credit Proposals, Briefing Note no. 22, Institute for Fiscal Studies, London, 2002 (www.ifs.org.uk/pensions/bn22.pdf).

\footnotetext{
${ }^{16}$ Housing benefit is withdrawn at a rate of $65 \%$ and council tax benefit at a rate of $20 \%$. These rates are additive, so an individual on the taper of both benefits will face a combined withdrawal rate of $85 \%$. Those also on the taper of the pension credit will lose an additional $40 \%$ of the remaining $15 \%$. This leaves $9 \%$ of the increase in income - i.e. a total withdrawal rate of $91 \%$.

${ }^{17}$ See M. Brewer and T. Clark, 'The impact on incentives of five years of social security reforms in the UK', Institute for Fiscal Studies, Working Paper no. 02/14, 2002 (www.ifs.org.uk/workingpapers/wp0214.pdf).
} 
Table 2. Percentage of families entitled to means-tested benefits, before and after the pension credit reform

\begin{tabular}{l|cccccc}
\hline & \multicolumn{5}{|c}{ Age } \\
& $50-59$ & $60-64$ & $65-74$ & $75+$ & All 50+ & All 60+ \\
\hline Before pension credit reform & & & & & & \\
Single men & 44.7 & 52.5 & 55.3 & 62.9 & 53.0 & 57.9 \\
Single women & 45.6 & 56.5 & 65.9 & 75.5 & 65.4 & 69.6 \\
Couples & 9.9 & 24.7 & 33.2 & 51.5 & 23.8 & 34.8 \\
All & 20.7 & 34.7 & 47.4 & 66.2 & 40.6 & 51.4 \\
& & & & & & \\
After pension credit reform & & & & & & \\
Single men & 44.7 & 55.1 & 63.8 & 72.2 & 57.8 & 65.5 \\
Single women & 46.0 & 57.9 & 73.5 & 81.8 & 70.7 & 75.9 \\
Couples & 9.9 & 27.0 & 40.9 & 61.3 & 27.4 & 41.3 \\
All & 20.7 & 36.8 & 55.2 & 74.1 & 44.9 & 58.0 \\
\hline
\end{tabular}

Note: In couples, age refers to the age of the older person in the couple.

Source: J. Banks, R. Blundell, R. Disney and C. Emmerson, Retirement, Pensions and the Adequacy of Saving: A Guide to the Debate, Briefing Note no. 29, Institute for Fiscal Studies, London, 2002 (www.ifs.org.uk/pensions/bn29.pdf).

The estimated impact of the pension credit on the percentage of older families that are eligible for means-tested benefits is shown in Table 2. Incomplete takeup, as discussed in Section 4, will mean that fewer families will actually be in receipt of means-tested benefits. Before the reform, 51.4\% of families with an individual aged 60 or over were eligible for means-tested benefits. The pension credit increased this percentage to $58.0 \%$. Families containing an older individual are found to be more likely to be eligible for means-tested benefits: among those families containing an individual aged 75 or over, $66.2 \%$ were eligible for means-tested benefits prior to the pension credit, and this percentage has since increased to $74.1 \%$. Table 2 also shows that single individuals are more likely to be eligible for means-tested benefits than couples. In addition, single women are more likely to be eligible for meanstested benefits than single men.

\section{What are the longer-term issues raised by the pension credit?}

The government has a firm commitment to index the pension credit in line with average earnings for the rest of the current parliament. In the longer term, it has an aspiration to continue this indexation. This is in contrast to the basic state pension, where the formal policy at least is only to continue indexing the benefit in line with inflation. ${ }^{18}$ The latest government projections for state spending on pensions including the pension credit are shown in Figure 6. The

\footnotetext{
${ }^{18}$ For this parliament, the government has stated that the basic state pension will increase by the greater of growth in the retail price index (RPI) and 2.5\%.
} 
figures assume that the basic state pension is indexed in line with prices and that the government's aspiration to increase the pension credit in line with average earnings is met.

Figure 6 shows that state spending is expected to remain broadly constant as a share of national income over the next 50 years, despite the large increase in the percentage of the population above the state pension age. This constancy is due to increases in expected state expenditure on the State Earnings-Related Pension Scheme (SERPS), the State Second Pension (S2P) and the pension credit being sufficient to offset the expected decline in expenditure on the basic state pension. The trend towards greater reliance on means-tested benefits is highlighted by the fact that while expenditure on the MIG / pension credit was only $10 \%$ of total state spending on pensions in 2001-02, it is expected to rise to $29 \%$ by $2051-52$. In contrast, the basic state pension today totals $75 \%$ of state expenditure on pensions and this is expected to decline to $42 \%$ in $2051-$ 52.

Figure 6. Projected state spending on pensions in the UK

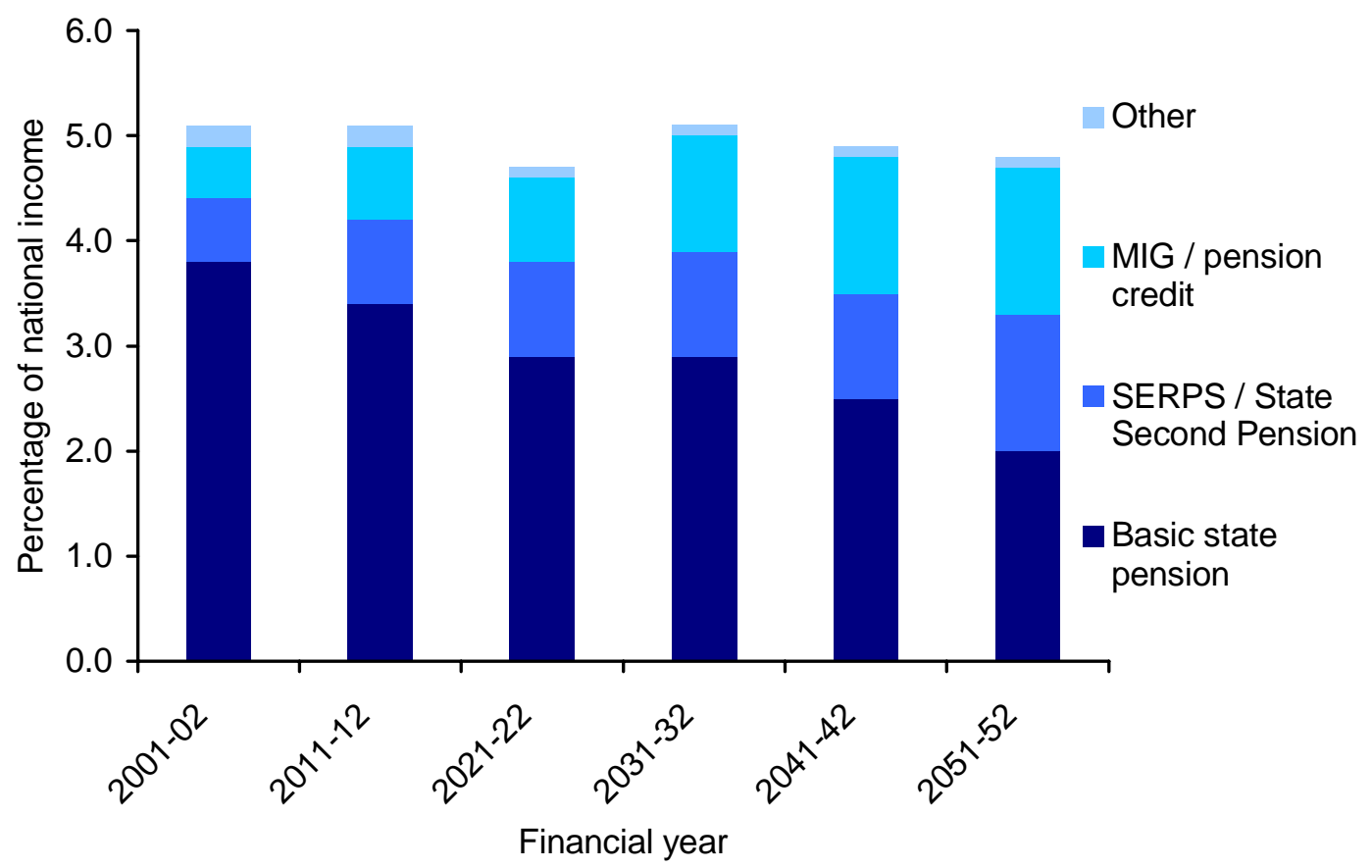

Source: Figure A3.1, page 148 of Department for Work and Pensions, Simplicity, Security and Choice: Working and Saving for Retirement, Cm. 5677, TSO, London, 2002 (www.dwp.gov.uk/consultations/consult/2002/pensions/gp.pdf).

There are at least four reasons why the projections contained in Figure 6 might understate eventual state spending:

- In the past, demographic forecasts have tended to underestimate improvements in mortality. 
- The projections assume that the basic state pension is indexed in line with prices, whereas political pressure might lead to it being increased by more than prices.

- The spending figures exclude the cost of all other means-tested and healthrelated benefits for which pensioners can be eligible. ${ }^{19}$

- Expenditure on means-tested benefits will depend, in part, on pensioners' private incomes, which might grow less quickly if means-tested benefits become relatively more generous. ${ }^{20}$

Leaving aside the uncertainty over the accuracy of the forecasts, it is of interest to see what impact the planned increase in reliance on means testing might have on the number of pensioners eligible for means-tested benefits. If the government keeps to its stated longer-term aim of increasing the basic state pension in line with prices but the pension credit in line with average earnings, then the gap between the two will increase at a rate greater than the growth of average earnings. Currently, that gap is $£ 23$ a week, or $12.3 \%$ of average earnings. Assuming real earnings growth of $2 \%$ a year, the gap would grow to $£ 78$, or $26.9 \%$ of average earnings, in $2025 .^{21}$

Estimating how many pensioners will be eligible for means-tested benefits in the future requires assumptions about the level of income that they are likely to receive from other sources. A simple assumption to make is to assume that retirement income, other than that from the basic state pension, increases in line with average earnings. Taking this and projecting forwards using the current pensioner population (which assumes that other factors also remain constant) suggests that the percentage of individuals aged 65 or over expected to be eligible for the pension credit would increase from 52\% in 2003 to $73 \%$ in 2025. By 2050, the percentage would rise further, to $82 \% .{ }^{22}$ Such an increase in

\footnotetext{
${ }^{19}$ For more details, see C. Emmerson, 'Pension reform in the United Kingdom: increasing the role of private provision?', in G. L. Clark and N. Whiteside (eds), Pension Security in the $21^{\text {st }}$ Century, Oxford University Press, Oxford, 2003.

${ }^{20}$ For example, under the assumption that pensioner incomes increase in line with prices, expenditure on the pension credit in 2050 would be estimated to be around 2 percentage points higher than the current government estimates. Source: House of Commons Hansard, 3 June 2003: column 391W.

${ }^{21}$ Source: table 4 of T. Clark and C. Emmerson, The Tax and Benefit System and the Decision to Invest in a Stakeholder Pension, Briefing Note no. 28, Institute for Fiscal Studies, London, 2002 (www.ifs.org.uk/public/bn28.pdf).

${ }^{22}$ Source: page 14 of T. Clark and C. Emmerson, The Tax and Benefit System and the Decision to Invest in a Stakeholder Pension, Briefing Note no. 28, Institute for Fiscal Studies, London, 2002 (www.ifs.org.uk/public/bn28.pdf).
} 
newly eligible individuals would make it more likely that the overall impact of the pension credit reform is to reduce private saving.

In practice, numbers eligible for the pension credit might grow more slowly than this because income from the State Second Pension should grow faster than average earnings as the new scheme will not reach maturity for around 50 years. Potentially offsetting this effect is the possibility that growth in private pensions might be slower than growth in average earnings. This might be particularly true if individuals choose to save less for retirement in the face of the changing incentives as the relative generosity of means-tested benefits increases over time. The Department for Work and Pensions has produced a similar analysis under the assumption that average real earnings grow at $1.5 \%$ a year and taking into account the growth in the State Second Pension. Its analysis suggests that the percentage of pensioners eligible for the pension credit will grow from $50 \%$ in 2004 to $65 \%$ in $2050 .^{23}$

\section{Conclusions}

The key findings of this Briefing Note are the following:

- The cost of the pension credit reform is approximately $£ 2$ billion a year. Just over half of families with an individual aged 65 or over are eligible. The reform is progressive, with average gains of $8 \%$ among the poorest tenth of households containing an individual aged 65 or over.

- The sort of teething problems that arose with the Inland Revenue's administration of the new tax credits for families with children should not reoccur with the pension credit - those who were in receipt of the MIG should automatically receive the pension credit.

- Expenditure on the pension credit is more closely targeted at supporting lower-income pensioners than an increase in the basic state pension. But the pension credit's effectiveness at reducing pensioner poverty will depend on take-up. The government has a relatively high take-up target of $73 \%$ of eligible households in 2006. Even if this target is met, it could leave almost 1 million pensioner households not in receipt of benefit to which they are entitled.

- Economic theory suggests that those who will be eligible for means-tested benefits as a result of the pension credit reform will reduce their retirement saving. The impact of the pension credit on the saving behaviour of those already expecting to be in receipt of means-tested benefits is ambiguous.

\footnotetext{
${ }^{23}$ See table 8 in annex B of Department for Work and Pensions, The Pension Credit: LongTerm Projections, London, 2002 (www.dwp.gov.uk/publications/dwp/2002/pencred/pencred.pdf).
} 
But the combined impact on aggregate (private plus public) saving is almost certain to be negative.

- If the government's stated aim of increasing the basic state pension in line with prices while increasing the pension credit in line with average earnings is met, then it is likely that an increasing percentage of families would be eligible. In this scenario, the longer-term impact of the pension credit would be even more likely to reduce private as well as aggregate saving.

- With regards to the government's objectives of giving more resources to low- to middle-income pensioners, rewarding pensioners for having saved in the past and encouraging people of working age to save for the future, the pension credit is likely to achieve the first two but not the third. 